\title{
Characterization of waterborne nitrogen emissions for marine eutrophication modelling in life cycle impact assessment at the damage level and global scale
}

\author{
Cosme, Nuno Miguel Dias; Hauschild, Michael Zwicky
}

Published in:

International Journal of Life Cycle Assessment

Link to article, DOI:

$10.1007 / \mathrm{s} 11367-017-1271-5$

Publication date:

2017

Document Version

Peer reviewed version

Link back to DTU Orbit

Citation (APA):

Cosme, N. M. D., \& Hauschild, M. Z. (2017). Characterization of waterborne nitrogen emissions for marine eutrophication modelling in life cycle impact assessment at the damage level and global scale. International Journal of Life Cycle Assessment, 22(10), 1558-1570. https://doi.org/10.1007/s11367-017-1271-5

\section{General rights}

Copyright and moral rights for the publications made accessible in the public portal are retained by the authors and/or other copyright owners and it is a condition of accessing publications that users recognise and abide by the legal requirements associated with these rights.

- Users may download and print one copy of any publication from the public portal for the purpose of private study or research.

- You may not further distribute the material or use it for any profit-making activity or commercial gain

- You may freely distribute the URL identifying the publication in the public portal 


\title{
Characterization of waterborne nitrogen emissions for marine eutrophication modelling in life cycle impact assessment at the damage level and global scale
}

Nuno Cosme*, Michael Z. Hauschild

Division for Quantitative Sustainability Assessment, Department of Management Engineering, Technical University of Denmark, Bygningstorvet 116B, DK-2800 Kgs. Lyngby, Denmark

*Corresponding author: Nuno Cosme (nmdc@dtu.dk; nmcosme@gmail.com)

\begin{abstract}
Purpose

Current life cycle impact assessment (LCIA) methods lack a consistent and globally applicable characterization model relating nitrogen $(\mathrm{N}$, as dissolved inorganic nitrogen, DIN) enrichment of coastal waters to the marine eutrophication impacts at the endpoint level. This paper introduces a method to calculate spatially explicit characterization factors (CF) at endpoint and damage to ecosystems levels, for waterborne nitrogen emissions, reflecting their hypoxia-related marine eutrophication impacts, modelled for 5,772 river basins of the world.
\end{abstract}

Methods

The proposed method combines environmental fate factors (FF) integrating (i) DIN-removal processes in soils and rivers, based on the NEWS 2-DIN model, and in coastal waters, based on water residence time, (ii) coastal ecosystem exposure (XF) to $\mathrm{N}$ enrichment, based on biological cycling processes, and (ii) effect factors (EF) based on species sensitivity to hypoxia. Three emission routes are discriminated as $\mathrm{N}$ from soil, $\mathrm{N}$ in emissions to river and to coastal waters. Damage factors (DF) are also estimated, based on endpoint metrics conversion from potentially affected to potentially disappeared fractions of species (i.e. PAF- to PDF. $\mathrm{m}^{3} \cdot \mathrm{yr} \cdot \mathrm{kgN}^{-1}$ ) and harmonization across coastal ecosystems based on spatially explicit density of demersal species, to further express $\mathrm{CF}$ as species $\cdot \mathrm{yr} \cdot \mathrm{kgN}^{-1}$. Results and discussion

Endpoint CFs show 6 orders of magnitude (o.m.) spatial differentiation among the river basins for the soil emission route, 4 for the river, and 2 for emissions to coastal waters. Damage CFs vary 7, 5 and 3 o.m. for the same routes. After aggregation at the level of continents, maximum CFs and DFs are consistently found in Europe, but the aggregation reduces spatial differentiation to $1 \mathrm{o} . \mathrm{m}$. for each route in both factors. The $\mathrm{FF}_{\mathrm{Nsoil}}$ and species density terms are responsible for most of the spatial differentiation of the damage model. Uncertainty is higher for the residence time term used in the FF model, due to scarcity and inconsistency of data sources, the assumptions of representativeness of DIN persistence and removal rates.

\section{Conclusions}

Major contributions to the current state-of-the-art of marine eutrophication characterization modelling are: (i) full pathway coverage, thus reaching damage level, (ii) significant increase in geographic coverage, (iii) mechanistic modelling of exposure and effect factors, and (iv) application of spatially explicit damage to ecosystems factors based on species densities. Application of the developed CFs in life cycle impact assessment is recommended at a river basin scale, provided that emission location is known.

Keywords Fate · Exposure · Effect · River basin · Endpoint · Characterization factors · Damage to ecosystem · LCIA 


\section{Table of Contents}

1 Introduction $\quad 2$

2 Methods $\quad 4$

2.1 Framework $r$

$\begin{array}{lll}2.1 .1 & \text { Nitrogen sources } & 4\end{array}$

2.1.2 Characterization factors in life cycle impact assessment 4

2.2 Fate factors $\quad 6$

$\begin{array}{ll}2.3 \text { Exposure factors } & 6\end{array}$

$\begin{array}{lll}2.4 & \text { Effect factors } & 7\end{array}$

$\begin{array}{ll}2.5 & \text { Spatially explicit damage factors }\end{array}$

3Results and discussion $\quad 9$

3.1 Characterization factors $r$

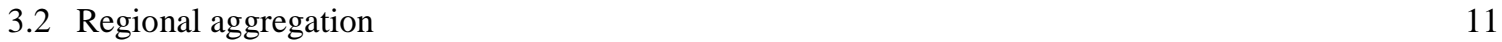

$\begin{array}{ll}3.3 \text { Sources of spatial differentiation } & 12\end{array}$

$\begin{array}{ll}3.4 \text { Sensitivity and uncertainties } & 12\end{array}$

$\begin{array}{lr}\text { 4Conclusions and outlook } & 14\end{array}$

Acknowledgements $\quad 15$

$\begin{array}{lr}\text { References } & 15\end{array}$

\section{Introduction}

Nitrogen $(\mathrm{N})$ is often a limiting growth factor for crops and forage species (Laegreid et al. 1999; Keeney and Hatfield 2001). Organic (manure) and inorganic (synthetic) fertilizers are widely used to supplement $\mathrm{N}$ to secure crop yields (Keeney and Hatfield 2001; Brady and Weil 2007). The increasing production of food and feed through fertilizer use in crops cultivation, and the increased energy production through fossil fuel combustion with associated emissions of nitrogen oxides, has resulted in a more than10-fold increase of reactive nitrogen creation in the last 150 years (Galloway et al. 2008). Human interventions currently mobilize more than twice the amount of reactive nitrogen than natural processes (Galloway et al. 2004), and river basins export 4-6 fold more dissolved inorganic nitrogen (DIN) than in the pre-industrial period (Galloway and Cowling 2002; Green et al. 2004). Riverine transport of such environmental emissions increases the $\mathrm{N}$ availability in coastal waters where they may cause impacts.

Marine coastal eutrophication refers to the syndrome of ecosystem responses to the increase in supply of organic matter (Nixon 1995; Cloern 2001). This definition encompasses all possible causes for such supply, e.g. increased algal growth following inorganic nutrients enrichment (an autochthonous source for organic carbon) or organic material loading (an allochthonous source), reduced grazing pressure on primary producers, and changes in water turbidity, residence time, circulation, stratification, or mixing. Any of these can, directly or indirectly, be affected by human interventions, but the increased supply of inorganic nutrients to coastal waters from anthropogenic sources (i.e. nutrient enrichment) has been identified as a clear link between human activities and ecosystem impacts (Smith et al. 1999; Gray et al. 2002; Rabalais 2002). The cascading effects of nutrient enrichment point to a variety of ecosystem impacts (Rabalais et al. 2009); one being the benthic oxygen depletion. This may lead to the onset of hypoxic waters, and if in excess, to anoxia and 'dead zones' - one of the most severe and widespread causes of disturbance to marine ecosystems (GESAMP 2001; Diaz and Rosenberg 2008). Other impact, like harmful algal blooms formation, hydrogen sulphide release from sediments, alterations in ecological community structure and functioning, and more - see e.g. Smith et al. (1999); Cloern (2001); Rabalais et al. (2009), are outside the scope of this study, but important nonetheless. 
The increased availability of growth-limiting nutrients in the well-lit upper layers of the ocean (euphotic zone) is an important trigger for eutrophication impacts as it promotes planktonic growth. Nitrogen is assumed to be this limiting nutrient in marine waters - a necessary and justified simplification in ecosystems modelling when considering average spatial and temporal representative conditions - see also Vitousek et al. (2002), Howarth and Marino (2006), Cosme et al. (2015). The Redfield ratio is usually adopted to describe the nutrients ratio assimilation by phytoplankton, i.e. C:N:P ratios of 106:16:1 (Flemming 1940; Redfield 1958). Nutrients assimilation and consequent particulate organic carbon export to bottom strata induces oxygen-consuming aerobic respiration by heterotrophic bacteria (Graf et al. 1982; Ploug et al. 1999; Cosme et al. 2015). The exposure of marine species to hypoxic conditions beyond their sensitivity thresholds threatens success and survival (Davis 1975; Diaz and Rosenberg 1995; Gray et al. 2002; VaquerSunyer and Duarte 2008; Cosme and Hauschild 2016), with ecological impacts extending to mass mortality or fisheries decline (Diaz and Rosenberg 1995; Wu 2002; Levin et al. 2009; Middelburg and Levin 2009; Zhang et al. 2010).

Life cycle impact assessment (LCIA) has been used as a tool to characterise the impacts of the environmental emissions originated throughout the entire life cycle of products and services in the economy (Hauschild 2005). Current LCIA methods typically model eutrophication impacts at a midpoint between emissions and damage to ecosystems. A consistent cause-effect link from emissions to the endpoint of the cascade of effects caused by the N-enrichment (impact pathway) is yet not available (Hauschild et al. 2013; Henderson 2015). To the knowledge of the authors, only the LCIA methods ReCiPe (Goedkoop et al. 2013; Huijbregts et al. 2016)and LIME (Itsubo and Inaba 2012) specifically model midpoint impacts for marine eutrophication, although restricted to European coverage and to a limited number of Japanese bays, respectively. Other methods, like EDIP2003 (Hauschild and Potting 2005), EPS (Steen 1999), LUCAS (Toffoletto et al. 2007), TRACI (Norris 2003), CML 2002 (Guinée et al. 2002) - also used in IMPACT 2002+ (Jolliet et al. 2003) and MEEuP (Kemna et al. 2005), showing a combined aquatic eutrophication indicator, are based on Redfield ratio's stoichiometric equivalencies to distinguish $\mathrm{N}$ and phosphorus (P) flows and model (with different degrees of environmental relevance) the fate of emitted substances (including $\mathrm{N}$ forms) based on e.g. air and water transport models, except in CML 2002 method. At the endpoint level, ReCiPe lacks the model work for marine eutrophication (EC-JRC 2010; Hauschild et al. 2013; Huijbregts et al. 2016) and LIME shows limited extrapolation beyond local Japanese application (Henderson 2015). The method IMPACT 2002+ distinguishes N- and P-limited waters but the endpoint model work is incomplete, has low relevance for marine systems, and is scoped to European conditions (Hauschild et al. 2013). In all cases, both at mid- and endpoint levels, spatial differentiation at a global scale is not modelled (generic or global indicators are used in CML 2002, EPS, MEEuP), or is at a coarse resolution (e.g. European countries in EDIP2003 and ReCiPe, U.S. states in TRACI) (Hauschild et al. 2013; Henderson 2015). Considering the importance of marine eutrophication in many regions of the world, an endpoint indicator that is consistent with the LCIA framework and spatially-explicit at a relevant resolution and global scale, would be a useful improvement to current impact assessment methodologies in LCA.

The goal of this study is to develop spatially-explicit characterization factors, at the levels of endpoint and damage to ecosystems, for waterborne nitrogen runoff from soils, and direct emissions to rivers and coastal waters. The factors represent the ability of those emissions to cause hypoxia-related eutrophication impacts. Firstly, the environmental fate of waterborne $\mathrm{N}$ emissions is modelled by accounting for the removal rates at the river basin scale and in the marine compartment. Secondly, the exposure of receiving ecosystems to $\mathrm{N}$ is mechanistically modelled by 
translating surface uptake of DIN into benthic oxygen depletion. Thirdly, the sensitivity of marine species to hypoxia is used to estimate potentially affected fractions of species using a species sensitivity distribution (SSD) method. Finally, species density is applied to estimate spatially explicit factors for damage to ecosystems. The resulting characterization factors have global coverage and are available for emission locations at a river basin spatial resolution, and also as emission-weighted continental and global aggregated factors. The importance of the contribution of each of the fate, exposure, effect, and damage factors is evaluated and the most important assumptions and uncertainties are discussed in support of LCIA application.

\section{Methods}

\subsection{Framework}

\subsubsection{Nitrogen sources}

Waterborne nitrogen emissions, as used here, refer to dissolved inorganic nitrogen (DIN) forms. These include nitrate $\left(\mathrm{NO}_{3}{ }^{-}\right)$, nitrite $\left(\mathrm{NO}_{2}{ }^{-}\right)$, and ammonium $\left(\mathrm{NH}_{4}{ }^{+}\right)$. The term DIN is generically applied in the text to refer to any of these forms.

The N-emission routes to the aquatic ecosystem include diffuse emissions from agricultural and natural soils $\left(\mathrm{N}_{\text {soil }}\right)$ to freshwater systems, point (direct) emissions to rivers $\left(\mathrm{N}_{\text {riv }}\right)$ and marine coastal waters $\left(\mathrm{N}_{\text {mar }}\right)$, and atmospheric deposition. The latter (airborne) is not modelled here, however, a quantified mass of nitrogen oxides $\left(\mathrm{NO}_{\mathrm{x}}\right)$ or ammonia $\left(\mathrm{NH}_{3}\right)$ deposited on soil, river, or marine water can be characterized using the factors for the emission routes for these compartments. The environmental emissions from soil correspond to the $\mathrm{N}$-surplus of the soil balance, which is defined as the difference between inputs and outputs for a certain given surface area. For that balance, inputs to natural and agricultural soils include biological fixation (i.e. the fixation of atmospheric $\mathrm{N}_{2}$ to, mainly, $\mathrm{NH}_{4}{ }^{+}$) and atmospheric deposition, and in agricultural soils also the application of $\mathrm{N}$-containing manure and synthetic fertilizers; outputs include $\mathrm{NH}_{3}$ volatilization, denitrification, and removal of $\mathrm{N}$ in plant biomass through harvesting and animal grazing (Bouwman et al. 2005; Bouwman et al. 2009). The soil balance modelling is considered part of the life cycle inventory (LCI) phase.

\subsubsection{Characterization factors in life cycle impact assessment}

The impact assessment phase in LCA applies characterization factors (CFs) to translate the quantified environmental emissions and consumption flows, identified in the inventory phase, into potential impacts on the chosen indicator for the impact category (Hauschild and Huijbregts 2015). The present work introduces CFs for DIN emissions from anthropogenic sources that contribute to eutrophication-induced hypoxia in coastal waters. The overall impact pathway for hypoxia-related eutrophication in coastal waters, illustrated in Fig. 1.A, covers the cause-effect chain from DIN inputs. These promote planktonic growth and eventually lead to the export of organic carbon to bottom waters where it is respired. This results in dissolved oxygen consumption and to potential loss of marine species richness and ecosystem damage.

The modelling work of the proposed characterization method is consistent with the LCIA framework for emission-related impact indicators (Udo de Haes et al. 2002; Pennington et al. 2004b) by including (i) an environmental 
fate model of DIN emissions in watersheds and river systems, aggregated at a river basin scale (Vörösmarty et al. 2000) and in coastal waters at large marine ecosystem (LME) scale (Sherman and Alexander 1986), (ii) an ecosystem exposure model for DIN uptaken by primary producers (phytoplankton) in coastal waters and the biological processes that result in oxygen depletion, and (iii) an effect model based on sensitivity of marine species to hypoxia. The factors derived from these models were multiplied to yield the endpoint $\mathrm{CF}\left(\left[(\mathrm{PAF}) \cdot \mathrm{m}^{3} \cdot \mathrm{yr} \cdot \mathrm{kgN}^{-1}\right]\right)$, as summarised in Eq. (1):

$C F_{i, j l}=F F_{i, j l} \times X F_{l} \times E F_{l}$

where $\mathrm{FF}_{i, j l}[\mathrm{yr}]$ is the fate factor for emission route $i$ in river basin $j$ to receiving ecosystem $l, \mathrm{XF}_{l}\left[\mathrm{kgO}_{2} \cdot \mathrm{kgN}^{-1}\right] \mathrm{the}$ ecosystem exposure factor and $\mathrm{EF}_{l}\left[(\mathrm{PAF}) \cdot \mathrm{m}^{3} \cdot \mathrm{kgO}_{2}^{-1}\right]$ the effect factor in ecosystem $l$. The latter is expressed as a Potentially Affected Fraction (PAF) of species to represent the impact dimension of species richness loss. PAF is included in the notation for informative purposes as it is in itself a dimensionless quantity (fraction) (Heijungs 2005). The CF and FF subscript notations show coupled $j l$ because each river basin exports to a single LME. The FF expresses the persistence of the exported fraction of the original $\mathrm{N}$-emission in each receiving coastal ecosystem (Cosme et al. 2017b). The XF represents the 'conversion' potential of $\mathrm{N}$ in the euphotic zone of coastal waters into oxygen depletion in bottom layers of the continental shelf (Cosme et al. 2015). The EF represents the average effect of hypoxic stress on demersal (benthic and benthopelagic) ecological communities exposed beyond the sensitivity threshold of the individual species (Cosme and Hauschild 2016). Each factor is further detailed in the next sections.

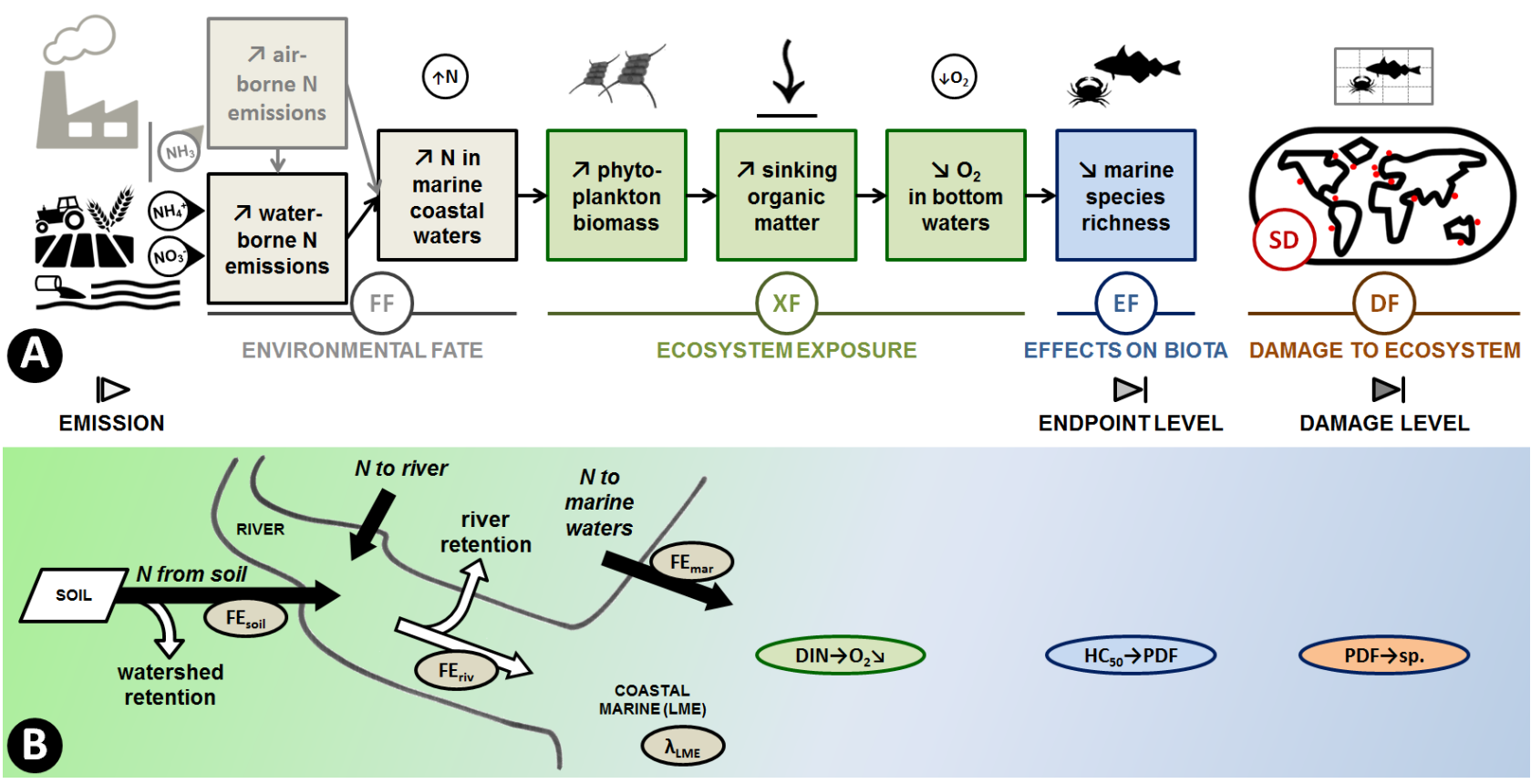

Fig. 1.A - Schematic representation of the impact pathway of waterborne nitrogen $(\mathrm{N})$ to hypoxia-related marine eutrophication impacts, showing the modelling components of the fate factor (FF), ecosystem exposure factor (XF), effect factor (EF) and damage factor (DF). Indication of endpoint and damage levels of impact indicators modelling. The fate modelling of airborne emissions from source to deposition is excluded. Adapted from (Cosme et al. 2017a). B - Representation of the key modelling points (coloured ovals) and their location in the model structure (refer to text for nomenclature used). Waterborne N-emissions sources (black arrows) identified by as diffuse (e.g soil, route " $\mathrm{N}$ from soil") and point (e.g. direct emissions to river, route " $\mathrm{N}$ to river", and to marine coastal waters, route " $\mathrm{N}$ to marine waters") 


\subsection{Fate factors}

The fate factor $(\mathrm{FF},[\mathrm{yr}])$ is composed of an inland fate component $\left(f_{\mathrm{N}}\right)$ and a marine fate component $(\lambda)$, as shown in Eq. (2).

$F F_{i, j l}=\frac{f_{N_{i, j}}}{\lambda_{l}}$

where $i$ is the emission route and $j$ the river basin that exports to the respective receiving $\operatorname{LME}(l)$.

The inland component was estimated by Cosme et al. (2017b) from the DIN-removal processes described in the second generation of the Global Nutrient Export from WaterSheds model (NEWS 2-DIN) (Seitzinger et al. 2010; Mayorga et al. 2010). Watershed export fractions (FE, dimensionless) were extracted from NEWS 2-DIN, corresponding to (i) calibrated runoff functions from land to streams $\left(\mathrm{FE}_{\text {soil }}\right)$ expressing the retention within soils, groundwater and riparian areas during transport to streams (treated as a permanent land sink) (Mayorga et al. 2010), and (ii) riverine DIN losses ( $\mathrm{FE}_{\text {riv }}$ ) involving transformation to unreactive forms, long-term but temporary storage, and permanent loss, by means of denitrification, retention, and water consumption (Dumont et al. 2005; Mayorga et al. 2010) - see also Fig. 1.B. Cosme et al. (2017b) applied combinations of these export fractions to estimate river basin-dependent fate coefficients $(f)$ for two emission routes: $f_{N_{\text {soil }}}=F E_{\text {soil }} \times F E_{\text {riv }}$ and $f_{N_{\text {riv }}}=F E_{\text {riv }}$. Direct emissions to marine waters have no watershed component, therefore $F E_{\text {mar }}=1$ and $f_{N_{\text {mar }}}=1$. The $f$-values correspond to fractions of the original $\mathrm{N}$-emission that are exported as DIN by each of the modelled 5,772 watersheds, which were further linked to a receiving LME by means of river mouth's geographic location. Considering the three emission routes the possible number of $f_{\mathrm{N} i, j}$ amounts to 17,316 .

The marine fate component was estimated based on the sum of DIN-removal rates $\left(\lambda,\left[\mathrm{yr}^{-1}\right]\right)$ in each LME $(l)$, assuming first order removal processes as described by Cosme et al. (2017b). Removal processes refer to advection $\left(\lambda_{\text {adv }}\right)$, estimated as the inverse of the surface water residence time, and denitrification $\left(\lambda_{\text {denitr }}\right)$, estimated with an empirical relationship between the fraction of $\mathrm{N}$ denitrified and the water residence time in lakes, river reaches, estuaries and continental shelf (Seitzinger et al. 2006). The use of residence time to derive an advective transport removal has been described elsewhere for lakes, estuaries, and coastal waters (see e.g. Vollenweider 1976; Andrews and Müller 1983; Nixon et al. 1996; Dettmann 2001; Monsen et al. 2002; Seitzinger et al. 2006). Denitrification is a generic process in aquatic systems and found independent of salinity (Fear et al. 2005; Magalhães et al. 2005). Therefore, the modelling approaches for both the advection and denitrification removals were deemed adequate to represent N-losses in marine coastal waters. See Cosme et al. (2017b) for full method description and estimated FFs. Factors for the 5,772 river basins of the world are given in Table S.1.

\subsection{Exposure factors}

The ecosystem responds to the input of a growth limiting nutrient by increasing its uptake rate by primary producers (phytoplankton) in the euphotic zone of coastal waters. The resulting planktonic growth fuels the organic carbon cycles that eventually contribute to the vertical carbon export to bottom water layers. There, aerobic respiration of organic material by heterotrophic bacteria consumes dissolved oxygen. The biological processes of N-limited primary production (PP), metazoan consumption, and bacterial degradation, were modelled by Cosme et al. (2015) in four 
distinct carbon sinking routes to derive 'conversion' potentials of DIN-uptake into organic carbon and into oxygen consumption (Fig. 1.B). Such 'conversion' potentials were defined as ecosystem exposure factors ( $\left.\mathrm{XF},\left[\mathrm{kgO}_{2} \cdot \mathrm{kgN}^{-1}\right]\right)$. Model and results are available in Cosme et al. (2015) as spatially-explicit XFs for 66 LMEs worldwide, varying from $0.45 \mathrm{kgO}_{2} \cdot \mathrm{kgN}^{-1}$ in the central Arctic Ocean to $15.9 \mathrm{kgO}_{2} \cdot \mathrm{kgN}^{-1}$ in the Baltic Sea. Factors for all 66 LMEs are shown in Table S.2.

\subsection{Effect factors}

Another component of the ecosystem response to $\mathrm{N}$-inputs is the effect on biota. The sensitivity to hypoxia of 91 demersal marine species (including fishes, crustaceans, molluscs, echinoderms, annelids, and cnidarians) was used to model effect factors $\left(\mathrm{EF},\left[(\mathrm{PAF}) \cdot \mathrm{m}^{3} \cdot \mathrm{kgO}_{2}^{-1}\right]\right)$ for application in LCIA in model work described in Cosme and Hauschild (2016). There, species sensitivity distribution (SSD) statistical methodologies (Posthuma et al. 2002) were applied to integrate specific sensitivity data and estimate the average effect of hypoxia on demersal communities as an $\mathrm{HC}_{50}$ indicator, which represents the stressor intensity, i.e. dissolved oxygen (DO) depletion, that affects $50 \%$ of the exposed population above their individual sensitivity thresholds. The EFs were then calculated as the average variation of the effect on ecological communities occurring in demersal habitats (as a dimensionless $\triangle \mathrm{PAF}$ ) due to a variation of the stressor intensity (as $\Delta \mathrm{DO}$ in $\left[\mathrm{kgO}_{2} \cdot \mathrm{m}^{-3}\right]$ ) in receiving ecosystem $l$, Eq. (3), according to an average gradient approach and consistent with the current scientific consensus (Pennington et al. 2004a; Larsen and Hauschild 2007).

$E F_{l}=\frac{\Delta P A F_{l}}{\Delta D O_{l}}=\frac{0.5}{H C_{50 l}}$

Sensitivity thresholds to hypoxia and species representativeness are critical aspects. The species sensitivity dataset used by Cosme and Hauschild (2016) represent a best estimate available, with a reasonable coverage of distinct taxonomic groups but acknowledging the variability of experimental results and biological endpoints. They further apply an ambient water temperature-dependent function to the species sensitivity data to increase both the representativeness and the environmental relevance of the method. The EF estimation assumes that those species can sufficiently represent the demersal animal communities in each climate zone. 'Average conditions' were modelled there to reconcile temporal and spatial variations. The EFs are available at a five climate zone (CZ) scale as of 218 (PAF) $\cdot \mathrm{m}^{3} \cdot \mathrm{kgO}_{2}^{-1}$ in the polar $\mathrm{CZ}, 242(\mathrm{PAF}) \cdot \mathrm{m}^{3} \cdot \mathrm{kgO}_{2}^{-1}$ in the subpolar $\mathrm{CZ}, 278(\mathrm{PAF}) \cdot \mathrm{m}^{3} \cdot \mathrm{kgO}_{2}^{-1}$ in the temperate $\mathrm{CZ}$, $275(\mathrm{PAF}) \cdot \mathrm{m}^{3} \cdot \mathrm{kgO}_{2}^{-1}$ in the subtropical $\mathrm{CZ}$, and $306(\mathrm{PAF}) \cdot \mathrm{m}^{3} \cdot \mathrm{kgO}_{2}{ }^{-1}$ in the tropical $\mathrm{CZ}$ (Cosme and Hauschild 2016). Although produced at a CZ scale, EFs can be disaggregated for the LMEs composing each $\mathrm{CZ}$, as a function of the mean benthic water temperature, as described in Cosme and Hauschild (2016) and given in Table S.2.

\subsection{Spatially explicit damage factors}

The terms 'endpoint' and 'damage' are used interchangeably in LCA/LCIA literature. In the present context, 'endpoint' refers to the location on the cause-effect chain (environmental pathway), whereas 'damage' refers to the consequences on the area of protection (AoP) 'ecosystems' (the value that society wants to protect). In practice, both terms refer to the loss of biodiversity (quantified as species richness loss). For communication and clarity purposes, we distinguish between PAF- or PDF-based units (labelled as endpoint) and species-based units (labelled as damage). The conversion 
of the marine eutrophication endpoint CF from the PAF-based metric to a PDF-based metric aims at harmonization of the endpoint scores in the LCIA framework.

Given the seasonality of the planktonic production and other biologically-mediated processes, water temperature and stratification, and nutrient emission flows, for an annual integration of marine eutrophication impacts to the ecosystem, a conversion factor of 0.5 was chosen, as discussed in Cosme et al. (2016a). This assumption means that one half of the species affected above their sensitivity to hypoxia threshold (expressed in the PAF-integrated metric) would disappear (and be expressed in the PDF-integrated metric). Spatially explicit damage factors (DF, $\left[(\mathrm{PDF} / \mathrm{PAF}) \cdot\right.$ species $\left.\left.\cdot \mathrm{m}^{-3}\right]\right)$, based on demersal marine species density $(\mathrm{SD})$, were thus applied to translate a relative metric of PAF-based endpoint indicator to an absolute metric of [species·yr]. These conversions are summarised in Eq. (4) for any receiving ecosystem $l$ :

$D F_{l}=0.5(P D F) \cdot(P A F)^{-1} \cdot S D_{l}$

A similar approach is taken in the ReCiPe method (Huijbregts et al. 2016) but adopting a site-generic SD estimate. Spatially explicit SD values were estimated for the 66 LMEs (Table S.2) based on species distribution models (SDMs) (Jones and Cheung 2015; Cosme et al. 2017a) and applied here to calculate the marine eutrophication damage factors of the $\mathrm{N}$-emissions for each of the three emission routes. An ensemble of multiple species distribution models (SDM) was use to (i) estimate species occurrences and richness, (ii) increase the robustness of the estimation method, as suggested by Jones and Cheung (2015), and (iii) minimize representativeness concerns and data-related uncertainty of estimating LME-dependent SDs based on fisheries catch statistics.

The harmonization with species densities is introduced because PDF-based units of indicators for different impact categories represent distinct biotic components of the respective ecosystems. As an example, freshwater and marine eutrophication impact scores, both expressed as a PDF-integrated metric, refer to a fraction of a necessarily distinct set of species, namely the freshwater and the marine biota. The aggregation of these un-matching indicator scores in a common AoP score would lead to a meaningless result and there is thus need for harmonization. In the present method, this is achieved by applying LME-dependent SDs in order to determine the absolute number of relevant species that the PDF refers to. Such species-based metric, ideally representative, can then be aggregated with equivalent results for other indicators contributing to the same AoP in a harmonized and meaningful damage score.

In order to understand the influence of spatial variability in environmental mechanisms in the variability of the damage model results, the contribution of each parameter (FF, XF, EF, SD) to the spatial variation of DF was assessed for each emission route by means of simple regression analysis on a log scale. Indications of lack of correlation are slopes far from 1.0, low coefficients of determination $\left(R^{2}\right)$, high sum of squares (SS), mean square (MS, the variance estimated from the residual sum of squares), and high standard error (SE).

Spatial aggregation of endpoint and damage CFs over regions, e.g. continents or world, for each N-emission route $i$, were calculated by emission-weighted averages (see calculation method in Section S.3). Regional factors $\left(\mathrm{CF}_{i, \text { reg }},\left[(\mathrm{PDF}) \cdot \mathrm{m}^{3} \cdot \mathrm{yr} \cdot \mathrm{kgN}^{-1}\right]\right.$ and $\left[\right.$ species $\left.\left.\cdot \mathrm{yr} \cdot \mathrm{kgN}^{-1}\right]\right)$ aggregate all emissions, with non-zero $\mathrm{CF}_{i, j l}$, belonging to region reg, with a corresponding emission in the respective route $i$. Emission data used refer to year 2000 and were extracted from the NEWS 2-DIN model (Mayorga et al. 2010). 


\section{Results and discussion}

\subsection{Characterization factors}

River basin-dependent endpoint characterization factors were calculated for the three emission routes according to Eq. (1) as the product of fate, exposure and effect factors. Table 1 shows these factors and the resulting CFs for the 12 largest rivers in the world in catchment area and for the emission route ' $\mathrm{N}$ from soil' $\left(\mathrm{N}_{\text {soil }}\right)$. Results for the 5,772 river basins and the three emission routes are given in full in Table S.1.

Fig. 2 shows the distribution of the CFs for the emission route ' $\mathrm{N}$ from soil' $\left(\mathrm{N}_{\text {soil }}\right)$ for the river basins of the world. Distribution maps of the endpoint CFs for the other two emission routes are presented in the Electronic Supplementary Material (Figs. S.1 and S.2).

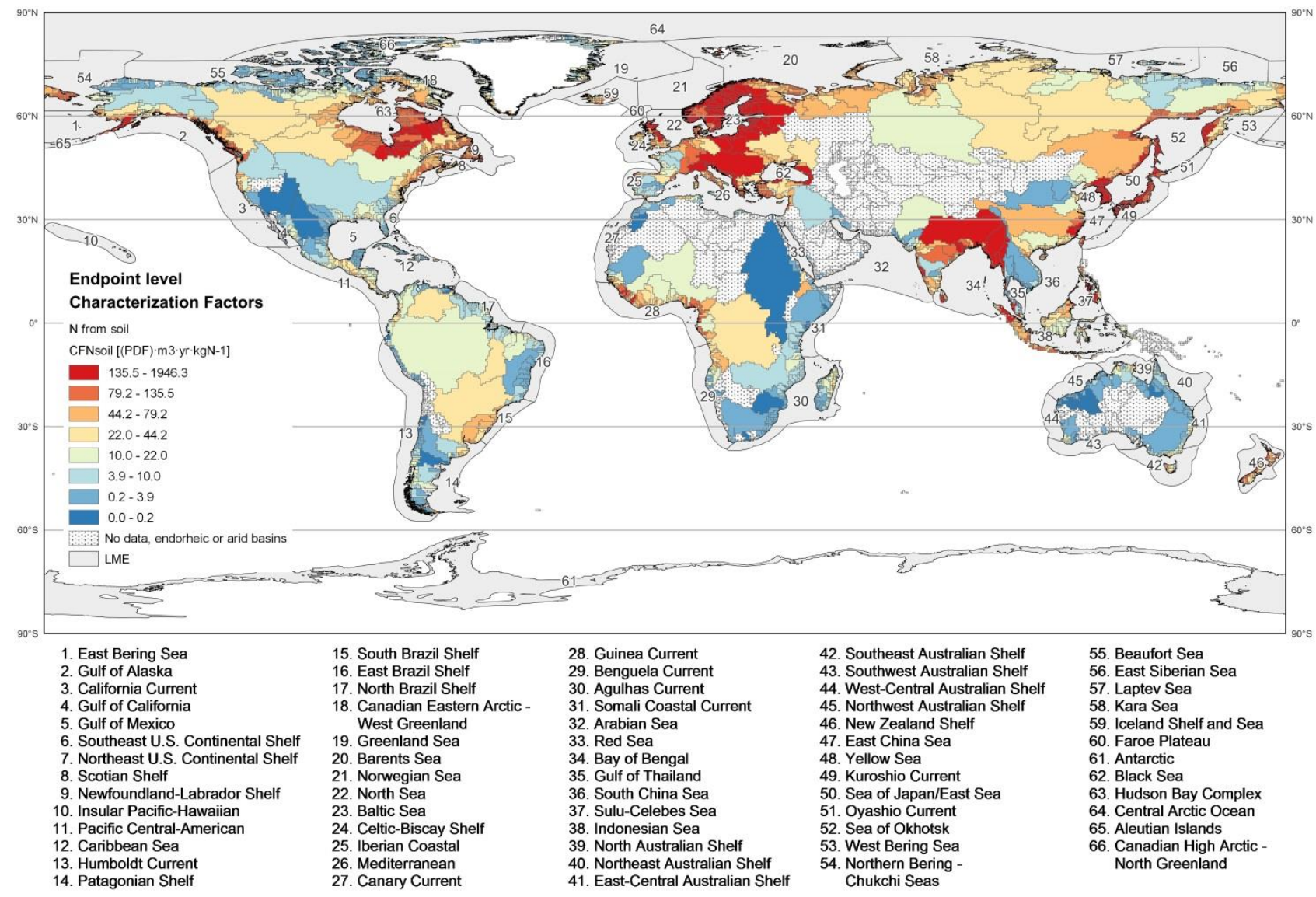

Fig. 2 Global distribution of the marine eutrophication endpoint characterization factors $\left(\mathrm{CF}_{\mathrm{Nsoil}},\left[(\mathrm{PDF}) \cdot \mathrm{m}^{3} \cdot \mathrm{yr} \cdot \mathrm{kgN}^{-1}\right]\right)$ for emissions of nitrogen $(\mathrm{N})$ from soil as DIN at a river basin scale. Note the non-linear scale. Similar distribution maps for the remaining emission routes can be found in the Electronic Supplementary Material 1

The endpoint CFs range from $1.7 \times 10^{-3}$ to $1.9 \times 10^{3}$ (for $\mathrm{N}_{\text {soil }}$ emission route), $3.1 \times 10^{-1}$ to $3.3 \times 10^{3}$ (for $\mathrm{N}_{\text {riv }}$ ), and $2.3 \times 10^{1}$ to $5.3 \times 10^{4}$ (for $\mathrm{N}_{\mathrm{mar}}$ ) (units in (PDF) $\cdot \mathrm{m}^{3} \cdot \mathrm{yr} \cdot \mathrm{kgN}^{-1}$ ) (Table S.3). These results correspond to spatial differentiations of 6 orders of magnitude for soil emissions, 4 for point emissions to river, and 2 for emissions to coastal waters. Higher CFs tend to occur in river basins discharging to LMEs with higher primary productivity and longer 
residence time, such as the Baltic Sea (LME \#23), Bay of Bengal (\#34), Sulu-Celebs Sea (\#37), Mediterranean Sea (\#26), Black Sea (\#62) and Hudson Bay Complex (\#63). Mean CF values, as well as spatially determined variation, decrease from emissions to coastal waters over river emissions and to soil emissions reflecting the increase in both $\mathrm{N}$ removal and spatial differentiation obtained by modelling riverine and watershed processes in the fate modelling.

The damage $\mathrm{CFs}$ [species $\cdot \mathrm{yr} \cdot \mathrm{kgN}^{-1}$ ] show an 10-fold increase in spatial differentiation when compared to endpoint $\mathrm{CFs}\left[(\mathrm{PAF}) \cdot \mathrm{m}^{3} \cdot \mathrm{yr} \cdot \mathrm{kgN}^{-1}\right]$ due to the introduction of LME-dependent species densities (extract of the results in Table 1 and in full in Table S.1 for the 5,772 river basins and the three emission routes; global distribution exemplified in Fig. 3 for the $\mathrm{N}_{\text {soil }}$ emission route, and given in Figs S.3 and S.4 for the remaining routes). Species density varies by 3 orders of magnitude among LMEs (Cosme et al. 2017a). Although studies have shown that water temperature variations may induce correlated changes in species occurrence (roughly poleward) (Cheung et al. 2008; Jones et al. 2012), this does not necessarily translate in a correlation between species density and temperature.

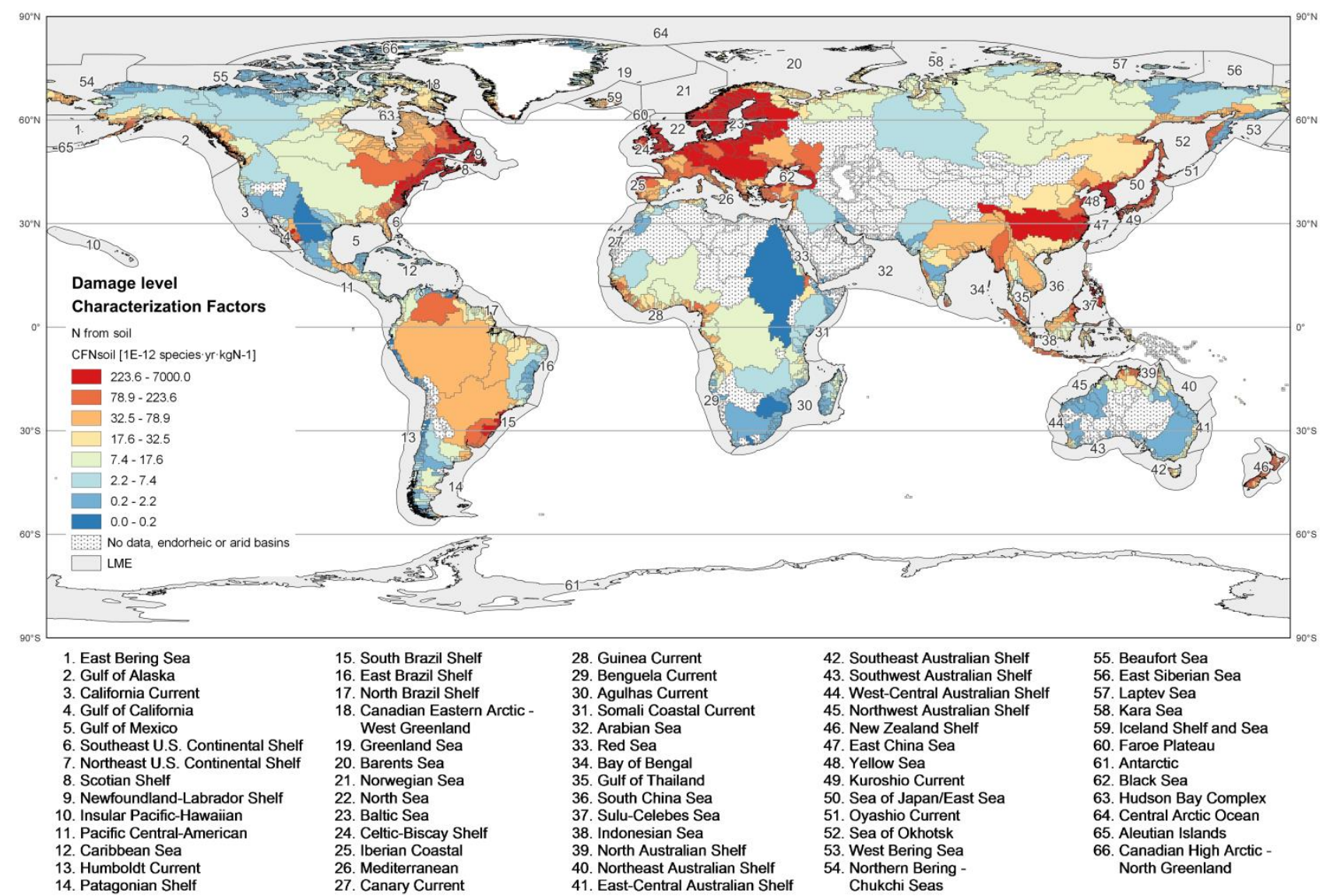

Fig. 3 Global distribution of the marine eutrophication characterization factors in damage level units $\left(\mathrm{CF}_{\mathrm{Nsoil}},\left[\mathrm{species} \cdot \mathrm{yr} \cdot \mathrm{kgN}^{-1}\right]\right)$ for emissions of nitrogen $(\mathrm{N})$ from soil as DIN at a river basin scale. Note the non-linear scale. Similar distribution maps for the remaining emission routes are available in the Electronic Supplementary Material 1

The damage CF values range from $4.7 \times 10^{-16}$ to $7.0 \times 10^{-9}$ (for $\mathrm{N}_{\text {soil }}$ ), $6.1 \times 10^{-14}$ to $1.2 \times 10^{-8}$ (for $\mathrm{N}_{\text {riv}}$ ), and $5.1 \times 10^{-12}$ to $1.9 \times 10^{-8}$ (for $\mathrm{N}_{\text {mar }}$ ) (units in species $\cdot \mathrm{yr} \cdot \mathrm{kgN}^{-1}$ ) (Table S.4). Such results correspond to 7 orders of magnitude of spatial differentiation for the soil emissions, 5 for the riverine emissions, and 3 for emissions to coastal waters, mostly given by the variation of the minimum values. Results decrease from coastal to river waters and to soils, i.e. towards upstream of 
the hydrological cycle flow. Comparing to the distribution pattern of the CFs at endpoint, damage CFs tend to show an intensification of the eutrophication potential towards river basins discharging to LMEs with denser species occurrence, namely in the Northeast and Southeast U.S. Continental Shelves (LME \#7 and \#6, respectively), Gulf of California (\#4), Gulf of Thailand (\#35), Iberian Coastal (\#25), Scotian Shelf (\#8), and Yellow Sea (\#48) (Cosme et al. 2017a).

Table 1 Extract of the results of the modelled fate, exposure and effect factors (FF, XF, and EF, respectively) and resulting characterization factors ( $\mathrm{CF}$, both in endpoint and damage level units) for the 12 rivers with the largest catchment area, and the emission route ' $\mathrm{N}$ from soil' $\left(\mathrm{N}_{\text {soil }}\right)$. Species density (SD) per Large Marine Ecosystem (LME) was used to estimate damage factors. Full results for the three emission routes and 5,772 river basins are given in Table S.5. Sources: FF (Cosme et al. 2017b), XF (Cosme et al. 2015), EF (Cosme and Hauschild 2016), SD (Cosme et al. 2017a)

\begin{tabular}{|c|c|c|c|c|c|c|c|c|}
\hline \multirow[t]{2}{*}{ River basin } & \multirow[t]{2}{*}{ Receiving LME } & \multirow{2}{*}{$\begin{array}{r}\mathrm{FF}_{\mathrm{Nsoil}} \\
\mathrm{yr}\end{array}$} & \multirow{2}{*}{$\begin{array}{r}\mathrm{XF} \\
\mathrm{kgO}_{2} \cdot \mathrm{kgN}^{-1}\end{array}$} & \multirow{2}{*}{$\begin{array}{r}\mathrm{EF} \\
(\mathrm{PAF}) \cdot \mathrm{m}^{3} \cdot \mathrm{kgO}_{2}^{-1}\end{array}$} & \multicolumn{2}{|c|}{$\mathrm{CF}_{\text {Nsoil }}$ (endpoint) } & \multirow{2}{*}{$\begin{array}{r}\mathrm{SD} \\
\mathrm{s} \cdot \mathrm{m}^{-3}\end{array}$} & \multirow{2}{*}{$\begin{array}{r}\mathrm{CF}_{\mathrm{Nsoil}} \text { (damage) } \\
\text { species } \cdot \mathrm{yr} \cdot \mathrm{kgN}^{-1}\end{array}$} \\
\hline & & & & & $(\mathrm{PAF}) \cdot \mathrm{m}^{3} \cdot \mathrm{yr} \cdot \mathrm{kgN}^{-1}$ & $(\mathrm{PDF}) \cdot \mathrm{m}^{3} \cdot \mathrm{yr} \cdot \mathrm{kgN}^{-1}$ & & \\
\hline Amazon & 17. North Brazil Shelf & 0.023 & 5.3 & 310 & 37 & 19 & $2.3 \mathrm{E}-12$ & $4.4 \mathrm{E}-11$ \\
\hline $\mathrm{Ob}$ & 58. Kara Sea & 0.032 & 6.2 & 220 & 44 & 22 & $2.8 \mathrm{E}-13$ & $6.2 \mathrm{E}-12$ \\
\hline Lena & 57. Laptev Sea & 0.039 & 7.5 & 220 & 64 & 32 & $5.2 \mathrm{E}-13$ & $1.7 \mathrm{E}-11$ \\
\hline Yenisei & 58. Kara Sea & 0.040 & 6.2 & 220 & 55 & 28 & $2.8 \mathrm{E}-13$ & 7.9E-12 \\
\hline Mississippi & 05. Gulf of Mexico & 0.0083 & 4.5 & 310 & 12 & 5.8 & $1.7 \mathrm{E}-12$ & $9.6 \mathrm{E}-12$ \\
\hline Nile & 26. Mediterranean & 0.00021 & 3.5 & 280 & 0.20 & 0.10 & $1.2 \mathrm{E}-12$ & $1.2 \mathrm{E}-13$ \\
\hline Zaire & 28. Guinea Current & 0.042 & 4.3 & 270 & 49 & 25 & $6.6 \mathrm{E}-13$ & $1.6 \mathrm{E}-11$ \\
\hline Mackenzie & 55. Beaufort Sea & 0.038 & 5.9 & 220 & 49 & 25 & $2.8 \mathrm{E}-13$ & $6.8 \mathrm{E}-12$ \\
\hline Parana & 14. Patagonian Shelf & 0.016 & 11 & 240 & 45 & 22 & $1.7 \mathrm{E}-12$ & 3.7E-11 \\
\hline Amur & 52. Sea of Okhotsk & 0.037 & 10 & 240 & 89 & 45 & $7.0 \mathrm{E}-13$ & $3.1 \mathrm{E}-11$ \\
\hline Niger & 28. Guinea Current & 0.031 & 4.3 & 270 & 36 & 18 & $6.6 \mathrm{E}-13$ & $1.2 \mathrm{E}-11$ \\
\hline Chang Jiang & 47. East China Sea & 0.062 & 6.4 & 310 & 120 & 62 & $5.6 \mathrm{E}-12$ & $3.5 \mathrm{E}-10$ \\
\hline
\end{tabular}

\subsection{Regional aggregation}

Endpoint CFs aggregated at the continental scale consistently show a maximum for Europe, followed by South Asia and Oceania for soil emissions, and North and South Asia for direct emission to river and marine waters (Table 2). The spatial variation of endpoint CFs aggregated at the level of continents ( 1 order of magnitude) is much lower than what is observed at the level of river basins, accompanied by little distinction between emission routes. Given the low spatial differentiation among continents (or large continental regions) those results suggest that, similarly to CFs generated by 'older' methods, or extrapolated from specific regions, the present model is unable to capture any significant differentiation and specificity of the impact pathway beyond a factor 10, at the spatial resolution of continents for these emission routes. Still, the estimation of the present CFs holds a mechanistic (and site-dependent) explanation and differentiation beyond site-generic factors. The intra-regional comparison shows slightly higher variability in the soil emissions (maximum in North and South America), than in the riverine (maximum in North America) and marine emissions (maximum in South Asia). In any case, a reduction of ca. 5, 3, and 1 order of magnitude is noticeable for the soil, riverine and marine emissions, respectively, when compared to the spatial differentiation obtained at the river basin scale. Such observations suggest a recommended use of the characterization factors at the river basin resolution for application in LCIA whenever the emission location is known. When only coarse spatial information on the emissions is available, regionally aggregated endpoint CFs may be used, noting the variability within the concerned continents. The global site-generic endpoint CF values can be used when such spatial information is not available or not relevant.

The analysis of the aggregated damage CFs shows similar observations (Table S.5). Europe consistently shows higher results at the level of continents and across the three emission routes. At this aggregation level, the spatial differentiation is modest, ca. 1 order of magnitude, with no relevant differences between emission routes. The intra- 
regional variability shows maximum differentiation for the soil emissions and decreasing towards river and marine emissions. North and South America consistently show higher variability in every emission route, although much smaller for marine emissions. Comparing the damage CFs at continental and river basin scales, spatial differentiation is reduced by 6, 4, and 2 orders of magnitude. As noted earlier for the endpoint CFs, and depending on the available information on the emissions location, damage CFs at a river basin scale are recommended for LCIA application, continental aggregation may be useful when only coarse spatial information is available (acknowledging the respective variability in each emission route), and the global site-generic value when emission location is unknown.

Table 2 Regional endpoint characterization factors CF $\left[(\mathrm{PDF}) \cdot \mathrm{m}^{3} \cdot \mathrm{yr} \cdot \mathrm{kgN}^{-1}\right]$ at the level of continents obtained by emission-weighted aggregation per emission route. Intra-regional variability (var) and inter-regional variability (Spatial variability of $\mathrm{N}_{i}$ ) factors shown

\begin{tabular}{|c|c|c|c|}
\hline \multirow[t]{2}{*}{ Aggregation scale } & \multicolumn{3}{|c|}{ Characterization Factor $\left[(\mathrm{PDF}) \cdot \mathrm{m}^{3} \cdot \mathrm{yr} \cdot \mathrm{kgN}^{-1}\right]$ per emission route } \\
\hline & $\mathrm{N}_{\text {soil }} v a r$ & $\mathrm{~N}_{\text {riv }} v a r$ & $\mathrm{~N}_{\operatorname{mar}} v a r$ \\
\hline Africa & $2.3 \mathrm{E}+011 E+04$ & $7.9 \mathrm{E}+017 E+02$ & $3.8 \mathrm{E}+022 E+01$ \\
\hline Europe & $1.4 \mathrm{E}+021 E+03$ & $5.1 \mathrm{E}+021 E+02$ & $1.4 \mathrm{E}+034 E+01$ \\
\hline North America & $3.1 \mathrm{E}+019 E+04$ & $7.8 \mathrm{E}+012 E+03$ & $2.2 \mathrm{E}+022 E+01$ \\
\hline South America & $2.3 \mathrm{E}+011 E+05$ & $6.3 \mathrm{E}+018 E+02$ & $2.1 \mathrm{E}+021 E+01$ \\
\hline North Asia & $4.8 \mathrm{E}+012 E+02$ & $2.6 \mathrm{E}+028 E+00$ & $7.5 \mathrm{E}+025 E+00$ \\
\hline South Asia & $1.3 \mathrm{E}+025 E+03$ & $2.3 \mathrm{E}+023 E+02$ & $9.0 \mathrm{E}+028 E+01$ \\
\hline Oceania $^{a}$ & $1.0 \mathrm{E}+024 E+03$ & $1.5 \mathrm{E}+023 E+01$ & $3.3 \mathrm{E}+023 E+01$ \\
\hline Australia & $1.4 \mathrm{E}+017 E+02$ & $4.7 \mathrm{E}+018 E+00$ & $1.1 \mathrm{E}+023 E+00$ \\
\hline Spatial variability & $1 E+01--$ & $1 E+01--$ & $1 E+01--$ \\
\hline World & $8.6 \mathrm{E}+01--$ & $2.0 \mathrm{E}+02--$ & $6.7 \mathrm{E}+02--$ \\
\hline
\end{tabular}

\subsection{Sources of spatial differentiation}

The results of the regression analysis of the variation of the parameters contributing to the variation of the damage model CFs, at a river basin scale, are shown in Table S.6 for each of the three emission routes. The analysis shows low explained variance of the $\mathrm{XF}$ and $\mathrm{EF}$ (and $\mathrm{XF} \times \mathrm{EF}$ ), slopes deviating from 1.0, and relatively high mean square (MS) and standard error (SE). These results suggest a poor correlation to damage CF variability, which means that neither the XF nor the EF alone are able explain the spatial variability of the damage model for any of the emission routes.

The soil-related fate factors $\left(\mathrm{FF}_{\mathrm{Nsoil}}\right)$ show stronger correlation to damage $\mathrm{CF}$. Overall, higher correlations in tests involving the FFs are observed for that emission route, suggesting that this factor is responsible for most of the spatial differentiation of the damage model results. Moreover, the SD variation shows reasonable correlation with damage $\mathrm{CF}$ variation, which can also be supported by the determinant application of the SD data in the damage factors estimation.

\subsection{Sensitivity and uncertainties}

The model sensitivity to the four primary input parameters, i.e. FF, XF, EF, and SD, was assessed by means of sensitivity ratios (SR) calculated as the ratio between the relative change in the model output and the relative change in the model input. As the damage CF calculation is a linear function of the parameters combination, i.e $\mathrm{CF}=\mathrm{FF} \times \mathrm{XF} \times \mathrm{EF} \times 0.5 \times \mathrm{SD}$, each of the primary parameters shows an expected $\mathrm{SR}=1.0$ (Table 3). Secondary parameters contributing to these were identified from the respective source modelling work and compared: 
- Soil and riverine export constants $\left(\mathrm{FE}_{\mathrm{soil}}\right.$ and $\left.\mathrm{FE}_{\mathrm{riv}}\right)$ contributing to soil and river FFs, and LME-dependent water residence time $\left(\tau_{\mathrm{LME}}\right)$ contributing to marine DIN removal (in $\mathrm{FF}_{\mathrm{Nmar}}$ ), all assessed by Cosme et al. (2017b);

- LME-dependent primary production rates $\left(\mathrm{PP}_{\mathrm{LME}}\right)$, secondary producers assimilation fraction $\left(f_{\text {SPassimil }}\right)$, and primary producers sinking fraction $\left(f_{\mathrm{PPsink}}\right)$, i.e. the three parameters contributing to XF with highest SRs, assessed by Cosme et al. (2015); and

- Species sensitivity to hypoxia (as a lowest-observed-effect-concentration, LOEC) determining the EF, for which SRs were estimated from the model work by Cosme and Hauschild (2016).

Table 3 Sensitivity ratios (SRs, unitless) of the primary and secondary input parameters for the damage factor estimation model. See text for parameters description

\begin{tabular}{llrl}
\hline Parameter & Type, contribution to & SR & Source \\
\hline $\mathrm{FF}_{\mathrm{N} i}$ & Primary, to $\mathrm{CF}_{\mathrm{N} i}$ and $\mathrm{DF}_{\mathrm{N} i}$ & 1.0 & This work \\
$\mathrm{XF}_{j}$ & Primary, to $\mathrm{CF}_{\mathrm{N} i}$ and $\mathrm{DF}_{\mathrm{N} i}$ & 1.0 & This work \\
$\mathrm{EF}_{j}$ & Primary, to $\mathrm{CF}_{\mathrm{N} i}$ and $\mathrm{DF}_{\mathrm{N} i}$ & 1.0 & This work \\
$\mathrm{SD}_{j}$ & Primary, to $\mathrm{DF}_{\mathrm{N} i}$ & 1.0 & This work \\
$\mathrm{FE}_{\text {soil }}$ & Secondary, to $\mathrm{FF}_{\mathrm{Nsoil}}$ & 1.0 & Cosme et al. (2017b) \\
$\mathrm{FE}_{\text {riv }}$ & Secondary, to $\mathrm{FF}_{\mathrm{Nsoil}}$ and $\mathrm{FF}_{\mathrm{Nriv}}$ & 1.0 & Cosme et al. (2017b) \\
$\tau_{\mathrm{LME}}$ & Secondary, to $\mathrm{FF}_{i j l}$ & 0.64 & Cosme et al. (2017b) \\
$\mathrm{PP}_{\mathrm{LME}}$ & Secondary, to $\mathrm{XF}_{j}$ & 0.92 & Cosme et al. (2015) \\
$f_{\mathrm{SPassimil}}$ & Secondary, to $\mathrm{XF}_{j}$ & -0.59 & Cosme et al. (2015) \\
$f_{\mathrm{PPsink}}$ & Secondary, to $\mathrm{XF}_{j}$ & 0.51 & Cosme et al. (2015) \\
LOEC & Secondary, to $\mathrm{EF}_{j}$ & $0.001-0.027$ & Using the model work by Cosme and Hauschild (2016) \\
\hline
\end{tabular}

The XF parameter $\mathrm{PP}_{\mathrm{LME}}$ shows a relatively higher contribution among the secondary parameters. The estimation of PP rates is associated with low uncertainty - the rates integrate monthly records from a 12-year period of satellite data, applies validated algorithms, and shows low variability (Cosme et al. 2015). The uncertainty of the FF parameter $\tau_{\mathrm{LME}}$ may be a key issue in the damage modelling work, considering (i) the assumption that surface water residence time is representative of DIN persistence in LMEs (Cosme et al. 2017b), (ii) the concerns about the inconsistency and scarcity of literature sources in reporting LME-integrated water residence time reported (Cosme et al. 2017b), (iii) the empirical relationship linking N-removal by denitrification and water residence time $\left(R^{2}=0.56\right)$, identified as a significant source of uncertainty (Cosme et al. 2017b), and (iv) that the parameter is applied in all three emission routes as an essential term in the marine compartment losses estimation. Ensuring its quality and consistency across LMEs seems essential. This is also supported by the analysis of the statistics of the distribution of endpoint CFs (Table S.3) the marine fate component $\left(\lambda_{\mathrm{LME}}\right)$, based on the $\tau_{\mathrm{LME}}$ term, contributes with 2 orders of magnitude variation to the $\mathrm{N}_{\text {mar }}$ route. The variation of the residence time parameter (almost 3 orders of magnitude) (Cosme et al. 2017b) is attenuated by the modest variation of XF (factor 35) (Cosme et al. 2015) and negligible variation of the EF (Cosme and Hauschild 2016) when composing the $\mathrm{CF}_{\mathrm{Nmar}}$. The variation of the $\mathrm{FE}_{\mathrm{riv}}$ and $\mathrm{FE}_{\text {soil }}$ terms add 2 orders of magnitude each to the spatial variability.

The validation work of the NEWS 2-DIN model, from which the specific DIN-removal fractions in the soil and river compartments were extracted, points to a reasonably robust model, as discussed in Mayorga et al. (2010). The NEWS 2-DIN calibration against observed DIN yields at the mouths of 66 basins (catchment areas from 28 to 5,847 
$\times 10^{3} \mathrm{~km}^{2}$ ) across the world shows reasonable robustness - explained variance $R^{2}=0.54$ in predicted vs. observed DIN yields, and an absolute model error of 6\% (Mayorga et al. 2010). Only the removal fraction constants are applied here, so the model error is likely to be smaller as the emission data necessary to estimate riverine yields in NEWS-2 DIN, and their inherent uncertainty, are not used. The NEWS 2 models suite is based on regression models that aggregate the environmental processes into export constants at a river basin scale, and thus miss the non-linearity of biogeochemical processes of $\mathrm{N}$ sinks in soil and groundwater, as discussed in Beusen et al. (2015). These fate processes are modelled in the IMAGE-GNM model (Beusen et al. 2015) also at a $0.5^{\circ} \times 0.5^{\circ}$ grid cell resolution. Its adoption could be a model improvement, providing that the relevant removal constants can be extracted. Nevertheless, the river basin scale modelling given by the NEWS 2-DIN model seems adequate and sufficient for the present purpose, as discussed in Cosme et al. (2017b).

The geographic distribution pattern of the CFs at endpoint (Fig. 2, Fig. S.1 and Fig. S.2) and damage levels (Fig. 3, Fig. S.3 and Fig. S.4) shows these factors' tendency to increase towards LMEs with higher primary productivity and longer residence time, justifying the attention given above to the quality of the $\mathrm{PP}_{\mathrm{LME}}$ and $\tau_{\mathrm{LME}}$ parameters.

In the EF model, the variability of the input data for the individual species sensitivity to hypoxia is minimised by the estimation method recommended by Cosme and Hauschild (2016), i.e. $\mathrm{GM}_{\mathrm{taxon}}$ or the geometric mean at taxonomic groups level of the geometric means of the species LOECs.

The PAF to PDF conversion applied in the DF estimation is based on an arbitrary site-generic 0.5 factor. Conversion coefficients based on species vulnerability, recoverability, ecological function, or on ecosystems resilience or services, can be used to estimate LME-dependent conversions - see discussion in Cosme et al. (2017a) and work by Curran et al. (2011), Verones et al. (2013) and Verones et al. (2015). While methods for such conversions are not widespread for demersal marine species in particular, the fixed 0.5 factor conversion holds, as proposed here.

The dataset used to estimate LME-dependent SDs is based on fisheries catch statistics, which may raise representativeness concerns and data-related uncertainty - see discussion in Cosme et al. (2017a). The use of a multiple species distribution models (SDM) ensemble increases the robustness of the species occurrence estimation, essential for the SD calculation. The SD estimation method described by Cosme et al. (2017a) seems the best estimate available and a valid addition to the indicators metrics harmonization effort.

Regional aggregation of CFs based on emission-weighted averages uses emission data from year 2000. The emission data may vary significantly over time and scale (Seitzinger et al. 2010; Beusen et al. 2016), requiring periodic update. However, when averaging up to the continental level, it is likely that the uncertainty of these data is of minor importance.

\section{Conclusions and outlook}

Impact assessment of human activities in a life cycle context is supported by characterization of the inventoried environmental emissions. Completeness and relevance of the underlying modelling work in the characterization phase are essential features for the model analysis (Hauschild et al. 2013). The marine eutrophication impact pathway defined in the present method (Fig. 1.A), aiming at the hypoxia-related impacts on demersal animal communities, covers the entire cascade of critical processes involved in this phenomenon; other pathways, with equally important impacts, fall outside the scope of the present work. Further, the sub-models applied in composing this particular damage indicator for 
marine eutrophication, i.e. environmental fate, ecosystem exposure, and effect factors, are based on documented stateof-the-art scientific knowledge, and their applicability and limitations are identified and discussed in the respective publications.

Major contributions to the current state-of-the-art of this impact category indicator resides in (i) the full pathway coverage reaching damage level, (ii) the significant increase in geographic coverage of both endpoint characterization and damage to ecosystem factors, (iii) the mechanistic modelling of ecosystem exposure and effect factors, and (iv) the application of spatially explicit species densities in the damage to ecosystems estimation.

Up to six and seven orders of magnitude spatial differentiation were verified for the characterization factors at endpoint and damage levels, respectively. In both cases, this differentiation is reduced to only 1 order of magnitude after aggregation to the level of continents. The application of the characterization factors, at both levels, is therefore recommended at a river basin scale, provided that emission location is known.

The transparency, relevance, and completeness of the method, advocate for its application in the characterization of waterborne nitrogen emissions in LCIA. The need for further work to implement environmental fate of airborne nitrogen emissions is acknowledged in order to achieve full coverage of the relevant environmental mechanisms involved in the marine eutrophication phenomenon. As such, deposition fractions of airborne nitrogen forms, as done by e.g. Dentener et al. (2006) or Roy et al. (2012), may be coupled to the present characterization factors.

\section{Acknowledgements}

The present research was partially funded by the European Commission under the 7th Framework Programme on Environment; ENV.2009.3.3.2.1: LC-IMPACT - Improved Life Cycle Impact Assessment methods (LCIA) for better sustainability assessment of technologies, grant agreement number 243827.

\section{References}

Andrews JC, Müller H (1983) Space-time variability of nutrients in a lagoonal patch reef. Limnol Oceanogr 28:215227. doi: 10.4319/lo.1983.28.2.0215

Beusen AHW, Bouwman AF, Van Beek LPH, et al (2016) Global riverine N and P transport to ocean increased during the 20th century despite increased retention along the aquatic continuum. Biogeosciences 113:2441-2451. doi: 10.5194/bgd-12-20123-2015

Beusen AHW, Van Beek LPH, Bouwman AF, et al (2015) Coupling global models for hydrology and nutrient loading to simulate nitrogen and phosphorus retention in surface water - description of IMAGE-GNM and analysis of performance. Geosci Model Dev 8:4045-4067. doi: 10.5194/gmd-8-4045-2015

Bouwman AF, Beusen AHW, Billen G (2009) Human alteration of the global nitrogen and phosphorus soil balances for the period 1970-2050. Global Biogeochem Cycles 23:1-16. doi: 10.1029/2009GB003576

Bouwman AF, Van Drecht G, Knoop JM, et al (2005) Exploring changes in river nitrogen export to the world's oceans. Global Biogeochem Cycles 19:14. doi: 10.1029/2004GB002314

Brady NC, Weil RR (2007) The nature and properties of soils, 14th edn. Prentice Hall

Cheung WWL, Close C, Lam VWY, et al (2008) Application of macroecological theory to predict effects of climate change on global fisheries potential. Mar Ecol Prog Ser 365:187-197. doi: 10.3354/meps07414

Cloern JE (2001) Our evolving conceptual model of the coastal eutrophication problem. Mar Ecol Prog Ser 210:223253. doi: $10.3354 / \operatorname{meps} 210223$

Cosme N, Hauschild MZ (2016) Effect factors for marine eutrophication in LCIA based on species sensitivity to 
hypoxia. Ecol Indic 69:453-462. doi: 10.1016/j.ecolind.2016.04.006

Cosme N, Jones MC, Cheung WWL, Larsen HF (2017a) Spatial differentiation of marine eutrophication damage indicators based on species density. Ecol Indic 73:676-685. doi: 10.1016/j.ecolind.2016.10.026

Cosme N, Koski M, Hauschild MZ (2015) Exposure factors for marine eutrophication impacts assessment based on a mechanistic biological model. Ecol Modell 317:50-63. doi: 10.1016/j.ecolmodel.2015.09.005

Cosme N, Mayorga E, Hauschild MZ (2017b) Spatially explicit fate factors for waterborne nitrogen emissions at the global scale. Int J Life Cycle Assess submitted.

Curran M, de Baan L, De Schryver AM, et al (2011) Toward meaningful end points of biodiversity in life cycle assessment. Environ Sci Technol 45:70-9. doi: 10.1021/es101444k

Davis JC (1975) Minimal dissolved oxygen requirements of aquatic life with emphasis on Canadian species: a review. J Fish Res Board Canada 32:2295-2332.

Dentener FJ, Drevet J, Lamarque JF, et al (2006) Nitrogen and sulfur deposition on regional and global scales: A multimodel evaluation. Global Biogeochem Cycles 20:1-21. doi: 10.1029/2005GB002672

Dettmann EH (2001) Effect of Water Residence Time on Annual Export and Denitrification of Nitrogen in Estuaries: A Model Analysis. Estuaries 24:481-490.

Diaz RJ, Rosenberg R (2008) Spreading dead zones and consequences for marine ecosystems. Science (80- ) 321:926929. doi: 10.1126/science. 1156401

Diaz RJ, Rosenberg R (1995) Marine Benthic Hypoxia: a Review of Its Ecological Effects and the Behavioural Responses of Benthic Macrofauna. In: Ansell AD, Gibson RN, Barnes M (eds) Oceanography and Marine Biology: an Annual Review. UCL Press, pp 245-303

Dumont E, Harrison JA, Kroeze C, et al (2005) Global distribution and sources of dissolved inorganic nitrogen export to the coastal zone: Results from a spatially explicit, global model. Global Biogeochem Cycles 19:GB4S02. doi: $10.1029 / 2005$ GB002488

EC-JRC (2010) ILCD Handbook: Analysis of existing Environmental Impact Assessment methodologies for use in Life Cycle Assessment, 1st edit. Publications Office of the European Union, Luxembourg

Fear J, Thompson S, Gallo T, Paerl H (2005) Denitrification rates measured along a salinity gradient in the eutrophic Neuse River estuary, North Carolina, USA. Estuaries and Coasts 28:608-619. doi: 10.1007/BF02696071

Flemming R (1940) The composition of plankton and units for reporting populations and production. Proc Sixth Pac Sci Congr Calif 1939:535-540.

Galloway JN, Cowling EB (2002) Reactive nitrogen and the world: 200 years of change. Ambio 31:64-71. doi: $10.2307 / 4315217$

Galloway JN, Dentener FJ, Capone DG, et al (2004) Nitrogen cycles: past, present, and future. Biogeochemistry 70:153-226.

Galloway JN, Townsend AR, Erisman JW, et al (2008) Transformation of the Nitrogen Cycle: Recent Trends, Questions, and Potential Solutions. Science (80- ) 320:889-892. doi: 10.1126/science.1136674

GESAMP (2001) A Sea of Troubles. Rep. Stud. GESAMP No. 70. Joint Group of Experts on the Scientific Aspects of Marine Environmental Protection and Advisory Committee on Protection of the Sea.

Goedkoop M, Heijungs R, Huijbregts MAJ, et al (2013) ReCiPe 2008 - A life cycle impact assessment method which comprises harmonised category indicators at the midpoint and the endpoint level - First edition (version 1.08) Report I: Characterisation. Den Haag, the Netherlands

Graf G, Bengtsson W, Diesner U, et al (1982) Benthic response to sedimentation of a spring phytoplankton bloom: Process and budget. Mar Biol 67:201-208. doi: 10.1007/BF00401286

Gray JS, Wu RS, Or YY (2002) Effects of hypoxia and organic enrichment on the coastal marine environment. Mar Ecol Prog Ser 238:249-279.

Green PA, Vörösmarty CJ, Meybeck M, et al (2004) Pre-industrial and contemporary fluxes of nitrogen through rivers: a global assessment based on typology. Biogeochemistry 68:71-105. 
Guinée JB, Gorrée M, Heijungs R, et al (2002) Handbook on life cycle assessment. Operational guide to the ISO standards. I: LCA in perspective. IIa: Guide. IIb: Operational annex. III: Scientific background. Kluwer Academic Publishers, Dordrecht

Hauschild MZ (2005) Assessing Environmental Impacts in a Life-Cycle Perspective. Environ Sci Technol 39:81-88. doi: $10.1021 / \mathrm{es} 053190 \mathrm{~s}$

Hauschild MZ, Goedkoop M, Guinée JB, et al (2013) Identifying best existing practice for characterization modeling in life cycle impact assessment. Int J Life Cycle Assess 18:683-697. doi: 10.1007/s11367-012-0489-5

Hauschild MZ, Huijbregts MAJ (2015) Introducing Life Cycle Impact Assessment. In: Hauschild MZ, Huijbregts MAJ (eds) Life Cycle Impact Assessment, LCA Compendium - The Complete World of Life Cycle Assessment. Springer Science+Business Media, Dordrecht, pp 1-16

Hauschild MZ, Potting J (2005) Spatial Differentiation in Life Cycle Impact Assessment - The EDIP2003 methodology.

Heijungs R (2005) On the use of units in LCA. Int J Life Cycle Assess 10:173-176. doi: http://dx.doi.org/10.1065/lca2005.02.199

Henderson AD (2015) Eutrophication. In: Hauschild MZ, Huijbregts MAJ (eds) Life Cycle Impact Assessment, LCA Compendium - The Complete World of Life Cycle Assessment. Springer Science+Business Media Dordrecht, pp 177-196

Howarth RW, Marino R (2006) Nitrogen as the limiting nutrient for eutrophication in coastal marine ecosystems: Evolving views over three decades. Limnol Oceanogr 51:364-376. doi: 10.4319/lo.2006.51.1_part_2.0364

Huijbregts MAJ, Steinmann ZJN, Elshout PMF, et al (2016) ReCiPe 2016. A harmonized life cycle impact assessment method at midpoint and endpoint level. Report I: Characterization. RIVM Report 2016-0104. Bilthoven, the Netherlands

Itsubo N, Inaba A (2012) LIME2: Life-cycle Impact assessment Method based on Endpoint modeling. JLCA Newsl Life-Cycle Assess Soc Japan 12:16.

Jolliet O, Margni M, Charles R, et al (2003) Presenting a New Method IMPACT 2002+: A New Life Cycle Impact Assessment Methodology. Int J Life Cycle Assess 8:324-330.

Jones MC, Cheung WWL (2015) Multi-model ensemble projections of climate change effects on global marine biodiversity. ICES J Mar Sci 72:741-752. doi: 10.1093/icesjms/fsu172

Jones MC, Dye SR, Pinnegar JK, et al (2012) Modelling commercial fish distributions: Prediction and assessment using different approaches. Ecol Modell 225:133-145. doi: 10.1016/j.ecolmodel.2011.11.003

Keeney DR, Hatfield JL (2001) The Nitrogen cycle, historical perspectives, and current and potential future concerns. In: Follet RF, Hatfield JL (eds) Nitrogen in the Environment: Sources, Problems, and Management. Elsevier Science B.V., Amsterdam, The Netherlands, pp 3-16

Kemna R, van Elburg M, Li W, van Holsteijn R (2005) Methodology Study Eco-design of Energy-using Products: MEEuP methodology report. Delft

Laegreid M, Bockman OC, Kaarstad O (1999) Agriculture and Fertilizers. AB Int., New York

Larsen HF, Hauschild MZ (2007) LCA Methodology Evaluation of Ecotoxicity Effect Indicators for Use in LCIA. Int J Life Cycle Assess 12:24-33.

Levin LA, Ekau W, Gooday AJ, et al (2009) Effects of natural and human-induced hypoxia on coastal benthos. Biogeosciences 6:2063-2098.

Magalhães CM, Joye SB, Moreira RM, et al (2005) Effect of salinity and inorganic nitrogen concentrations on nitrification and denitrification rates in intertidal sediments and rocky biofilms of the Douro River estuary, Portugal. Water Res 39:1783-1794. doi: 10.1016/j.watres.2005.03.008

Mayorga E, Seitzinger SP, Harrison JA, et al (2010) Global Nutrient Export from WaterSheds 2 (NEWS 2): Model development and implementation. Environ Model Softw 25:837-853. doi: 10.1016/j.envsoft.2010.01.007

Middelburg JJ, Levin LA (2009) Coastal hypoxia and sediment biogeochemistry. Biogeosciences 6:1273-1293. doi: $10.5194 /$ bg-6-1273-2009 
Monsen NE, Cloern JE, Lucas L V., Monismith SG (2002) The use of flushing time, residence time, and age as transport time scales. Limnol Oceanogr 47:1545-1553. doi: 10.4319/lo.2002.47.5.1545

Nixon SW (1995) Coastal marine eutrophication: A definition, social causes, and future concerns. Ophelia 41:199-219.

Nixon SW, Ammerman JW, Atkinson LP, et al (1996) The fate of nitrogen and phosphorus at the land-sea margin of the North Atlantic Ocean. Biogeochemistry 35:141-180.

Norris GA (2003) Impact Characterization in the Tool for the Reduction and Assessment of Chemical and Other Environmental Impacts. J Ind Ecol 6:79-101. doi: 10.1162/108819802766269548

Pennington DW, Payet J, Hauschild MZ (2004a) Aquatic Ecotoxicological Indicators In Life-Cycle Assessment. Environ Toxicol Chem 23:1796-1807.

Pennington DW, Potting J, Finnveden G, et al (2004b) Life cycle assessment Part 2: Current impact assessment practice. Environ Int 30:721-39. doi: 10.1016/j.envint.2003.12.009

Ploug H, Grossart H-P, Azam, Farooq, Jørgensen BB (1999) Photosynthesis, respiration, and carbon turnover in sinking marine snow from surface waters of Southern California Bight: implications for the carbon cycle in the ocean. Mar Ecol Prog Ser 179:1-11.

Posthuma L, Suter II GW, Traas TP (eds) (2002) Species Sensitivity Distributions in Ecotoxicology. Lewis Publishers

Rabalais NN (2002) Nitrogen in Aquatic Ecosystems. Ambio 31:102-112.

Rabalais NN, Turner RE, Diaz RJ, Justić D (2009) Global change and eutrophication of coastal waters. ICES J Mar Sci 66:1528-1537.

Redfield AC (1958) The Biological Control of Chemical Factors in the Environment. Am Sci 46:205-221.

Roy P-O, Huijbregts MAJ, Deschênes L, Margni M (2012) Spatially-differentiated atmospheric source-receptor relationships for nitrogen oxides, sulfur oxides and ammonia emissions at the global scale for life cycle impact assessment. Atmos Environ 62:74-81. doi: 10.1016/j.atmosenv.2012.07.069

Seitzinger SP, Harrison JA, Böhlke JK, et al (2006) Denitrification across landscapes and waterscapes: A synthesis. Ecol Appl 16:2064-2090.

Seitzinger SP, Harrison JA, Dumont E, et al (2005) Sources and delivery of carbon, nitrogen, and phosphorus to the coastal zone: An overview of Global Nutrient Export from Watersheds (NEWS) models and their application. Global Biogeochem Cycles 19:1-11. doi: 10.1029/2005GB002606

Seitzinger SP, Mayorga E, Bouwman AF, et al (2010) Global river nutrient export: A scenario analysis of past and future trends. Global Biogeochem Cycles 24:GB0A08. doi: 10.1029/2009GB003587

Sherman K, Alexander LM (eds) (1986) Variability and Management of Large Marine Ecosystems. Westview Press Inc., Boulder, $\mathrm{CO}$

Smith VH, Tilman GD, Nekola JC (1999) Eutrophication: impacts of excess nutrient inputs on freshwater, marine, and terrestrial ecosystems. Environ Pollut 100:179-196.

Steen B (1999) A systematic approach to environmental priority strategies in product development (EPS). Version 2000 - General system characteristics. CPM report 1999:4. Gothenburg, Sweden

Toffoletto L, Bulle C, Godin J, et al (2007) LCA Methodology LUCAS - A New LCIA Method Used for a CAnadianSpecific Context. Int J Life Cycle Assess 12:93-102.

Udo de Haes HA, Finnveden G, Goedkoop M, et al (2002) Life-Cycle Impact Assessment: Striving Towards Best Practice. SETAC Press, Pensacola, FL, USA

Vaquer-Sunyer R, Duarte CM (2008) Thresholds of hypoxia for marine biodiversity. Proc Natl Acad Sci U S A 105:15452-7. doi: 10.1073/pnas.0803833105

Verones F, Huijbregts MAJ, Chaudhary A, et al (2015) Harmonizing the assessment of biodiversity effects from land and water use within LCA. Environ Sci Technol 49:3584-3592. doi: 10.1021/es504995r

Verones F, Saner D, Pfister S, et al (2013) Effects of consumptive water use on biodiversity in wetlands of international importance. Environ Sci Technol 47:12248-57. doi: 10.1021/es403635j 
Vitousek PM, Hättenschwiler S, Olander L, Allison S (2002) Nitrogen and nature. Ambio 31:97-101.

Vollenweider RA (1976) Advances in defining critical loading levels for phosphorus in lake eutrophication. Mem dell'Istituto Ital di Idrobiol dott Marco Marchi 33:53-83.

Vörösmarty CJ, Fekete BM, Meybeck M, Lammers RB (2000) Geomorphic attributes of the global system of river at 30-minute spatial resolution. J Hydrol 237:17-39.

Wu RS (2002) Hypoxia: from molecular responses to ecosystem responses. Mar Pollut Bull 45:35-45.

Zhang J, Gilbert D, Gooday AJ, et al (2010) Natural and human-induced hypoxia and consequences for coastal areas: synthesis and future development. Biogeosciences 7:1443-1467. doi: 10.5194/bg-7-1443-2010 